\title{
Toward the realization of cardiac regenerative medicine using pluripotent stem cells
}

\author{
Yoshikazu Kishino, Jun Fujita*, Shugo Tohyama, Marina Okada, Sho Tanosaki, Shota Someya and Keiichi Fukuda
}

\begin{abstract}
Heart transplantation $(H T)$ is the only radical treatment available for patients with end-stage heart failure that is refractory to optimal medical treatment and device therapies. However, HT as a therapeutic option is limited by marked donor shortage. To overcome this difficulty, regenerative medicine using human-induced pluripotent stem cells (hiPSCs) has drawn increasing attention as an alternative to HT.

Several issues including the preparation of clinical-grade hiPSCs, methods for large-scale culture and production of hiPSCs and cardiomyocytes, prevention of tumorigenesis secondary to contamination of undifferentiated stem cells and non-cardiomyocytes, and establishment of an effective transplantation strategy need to be addressed to fulfill this unmet medical need. The ongoing rapid technological advances in hiPSC research have been directed toward the clinical application of this technology, and currently, most issues have been satisfactorily addressed. Cell therapy using hiPSC-derived cardiomyocytes is expected to serve as an integral component of realistic medicine in the near future and is being potentially viewed as a treatment that would revolutionize the management of patients with severe heart failure.
\end{abstract}

Keywords: Regenerative medicine, Induced pluripotent stem cell, Cardiomyocyte

\section{Background}

In 2006, Yamanaka et al. introduced the genes Oct3/4, Sox2, Klf4, and $c-M y c$ (referred to as Yamanaka factors) into somatic cells in mice and successfully developed induced pluripotent stem cells (iPSCs) [1], which showed properties similar to those of embryonic stem cells (ESCs). In 2007, they developed human-iPSCs (hiPSCs) [2]. It is possible to elucidate the pathophysiology of several unknown genetic diseases using patient-derived hiPSCs, and these are also useful for novel drug screening. Thus, the emergence of hiPSCs is a promising therapeutic approach in patients with diseases that were previously considered incurable. Evaluation of the responsiveness of patientderived hiPSCs to drugs can determine the role of these cells in personalized medicine. Moreover, hiPSCs are drawing increasing attention as a revolutionary approach toward the rapid realization of regenerative medicine. This unique technology overcomes the challenges affecting

\footnotetext{
* Correspondence: jfujita@a6.keio.jp

Department of Cardiology, Keio University School of Medicine, 35 Shinanomachi, Shinjuku, Tokyo 160-8582, Japan
}

regenerative medicine research such as ethical issues and immune rejection reactions, which serve as significant drawbacks of ESCs derived from the inner cell mass that forms a part of the embryo (blastocyst stage).

End-stage heart failure is a significant contributor to the cardiovascular disease burden in adults. Unfortunately, this condition is refractory to medical treatment and device therapies. Heart transplantation (HT) is the only radical treatment available in the present era. However, a marked shortage of donor hearts limits the availability of HT as a therapeutic option, particularly in Japan. Currently, the number of patients undergoing HT is $<100$, and the waiting period to register for transplantation is $>3$ years (The Registry Report of Heart Transplantation in Japan 2016). Given this scenario, hiPSC-derived cardiomyocytes are considered an ideal cell source in patients requiring HT for severe heart failure [3].

In this review, we have discussed the current scenario with regard to the utility of hiPSC-derived cardiomyocytes in cardiac regenerative medicine, as well as their clinical application (Fig. 1).

(c) The Author(s). 2020 Open Access This article is distributed under the terms of the Creative Commons Attribution 4.0 International License (http://creativecommons.org/licenses/by/4.0/), which permits unrestricted use, distribution, and 


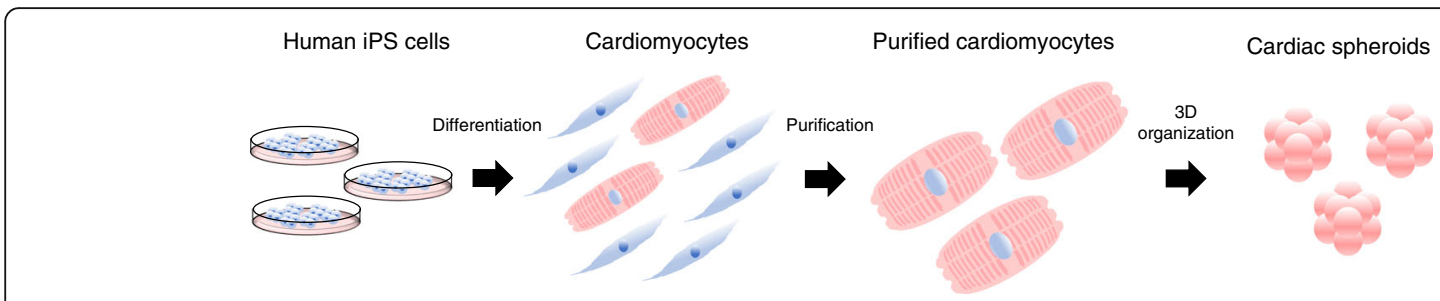

Fig. 1 Strategy of cardiac regenerative therapy using human iPSC-derived cardiomyocytes. iPSC, induced pluripotent stem cell

\section{Main text}

Protocols for cardiac differentiation of human pluripotent stem cells

Several researchers have reported cardiac differentiation of pluripotent stem cells (PSCs) to artificially generate human cardiomyocytes (Table 1). Regarding the induction of cardiomyocytes from human-PSCs (hPSCs), these can be induced to differentiate into cardiomyocytes at different sites within the heart, such as the atria, ventricles, and other such structures. Reportedly, these cells show the same characteristic electrical activity as demonstrated by human cardiomyocytes [19]. Protocols for the differentiation of hiPSCs into cardiomyocytes have been established based on the development and differentiation of the heart [18]. Currently, three- and two-dimensional culture methods are available for cardiac differentiation. The three-dimensional culture method generates large quantities of cardiomyocytes by suspension culture using a bioreactor or spinner flask [20]. However, this technology is expensive because it requires the use of recombinant

Table 1 Cardiac differentiation protocols

\begin{tabular}{|c|c|c|c|c|c|c|}
\hline Publication & $\begin{array}{l}\text { Differentiation } \\
\text { method }\end{array}$ & Media & Coating matrix & Mesoderm induction & Cardiac specification & Differentiation efficiency \\
\hline Kehat et al. [4] & EB formation & $\begin{array}{l}\text { KO DMEM + } \\
20 \% \text { FBS }\end{array}$ & Gelatin & NA & NA & $8.1 \%$ beating EBs \\
\hline Laflamme et al. [5] & Monolayer & $\begin{array}{l}\text { RPMI1640 + } \\
\text { B27 }\end{array}$ & Matrigel & Activin A, BMP4 & NA & $>30 \% \beta-\mathrm{MHC}(+) \mathrm{CMs}$ \\
\hline Yang et al. [6] & EB formation & Stempro34 & Gelatin & Activin A, BMP4, bFGF & VEGF, DKK1, bFGF & 40-50\% TNNT(+)CMs \\
\hline Tran et al. [7] & EB formation & $\begin{array}{l}\text { KO DMEM + } \\
15 \% \text { FBS }\end{array}$ & Gelatin & WNT3A & NA & $\begin{array}{l}\text { EB formation 10-folds } \\
\text { increase (vs control) }\end{array}$ \\
\hline Elliot et al. [8] & $\begin{array}{l}\text { EB formation or } \\
\text { monolayer }\end{array}$ & LI-APEL & Matrigel & $\begin{array}{l}\text { Activin A, BMP4, bFGF, } \\
\text { VEGF, SCF, WNT3A }\end{array}$ & NA & $\begin{array}{l}\text { EB:38\% Nkx2.5(+) cells } \\
\text { Monolayer:24\% Nkx2.5(+) } \\
\text { cells }\end{array}$ \\
\hline Kattman et al. [9] & EB formation & Stempro34 & NA & Activin A, BMP4, bFGF & $\begin{array}{l}\text { VEGF, DKK1, } \\
\text { TGF } \beta i \text {, BMPi }\end{array}$ & $>60 \%$ TNNT(+)CMs \\
\hline Zhang et al. [10] & Monolayer & $\begin{array}{l}\text { RPMI1640 + } \\
\text { B27 }\end{array}$ & Gelatin & Activin A, BMP4, bFGF & $\begin{array}{l}\text { NOGGIN, RA/RAi, } \\
\text { DKK1 }\end{array}$ & $\begin{array}{l}\text { RA: } 50.7 \% \pm 1.7 \% \\
\text { RAi:64.7\% } \pm 0.9 \%\end{array}$ \\
\hline Willems et al. [11] & EB formation & Stempro34 & Gelatin & Activin A, BMP4, bFGF & $\begin{array}{l}\text { bFGF, } \\
\text { IWR-1, triiodothyronine }\end{array}$ & $30 \% \mathrm{MYH} 6(+) \mathrm{CMs}$ \\
\hline Zhang et al. [12] & $\begin{array}{l}\text { Monolayer } \\
\text { (matrix sandwich) }\end{array}$ & $\begin{array}{l}\text { RPMI1640 + } \\
\text { B27 insulin(-) }\end{array}$ & Matrigel & Activin A, BMP4, bFGF & NA & 40-92\% TNNT(+)CMs \\
\hline Lian et al. [13] & Monolayer & $\begin{array}{l}\text { RPMI1640B27 } \\
\text { insulin(-) }\end{array}$ & $\begin{array}{l}\text { Matrigel or } \\
\text { Synthemax }\end{array}$ & CHIR99021 & IWP2 & 85\%TNNT(+)CMs \\
\hline Burridge et al. [14] & Monolayer & CDM3 & Vitronectin & CHIR99021 & Wnt-C59 & 80-95\% TNNT(+)CMs \\
\hline Devalla et al. [15] & EB formation & BPEL & Gelatin & $\begin{array}{l}\text { Activin A, BMP4, } \\
\text { CHIR99021, SCF, VEGF }\end{array}$ & RA & 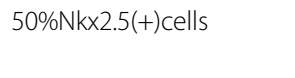 \\
\hline Protze et al. [16] & EB formation & Stempro34 & NA & Activin A, BMP4, bFGF & $\begin{array}{l}\text { IWP2, VEGF, BMP4, } \\
\text { RA, bFGFi, TGF } \beta i\end{array}$ & $\begin{array}{l}5 \% \mathrm{Nk} \times 2.5(+) \text { cells } \\
55 \% \mathrm{Nk} \times 2.5(-) \text { SANLPCs }\end{array}$ \\
\hline Tohyama et al. [17] & $\begin{array}{l}\text { Monolayer } \\
\text { (multilayer plates) }\end{array}$ & $\begin{array}{l}\text { RPMI1640 + } \\
\text { B27 insulin(-) }\end{array}$ & $\begin{array}{l}\text { Fibronectin or } \\
\text { type1 collagen }\end{array}$ & CHIR99021, BMP4 & IWR-1 & 80\%TNNT(+)CMs \\
\hline
\end{tabular}

Modified table taken from [18]

Abbreviations: $b F G F$ basic fibroblast growth factor, $b F G F i$ bFGF inhibitor, BMP bone morphologic protein, BMPi BMP inhibitor, CMs cardiomyocytes, DKK Dickkopf, $D M S O$ dimethyl sulfoxide, $E B$ embryoid body, FBS fetal bovine serum, $K O$ knockout, $M L C$ myosin light chain, N/A not applicable or not available, TGF $\beta$ transforming growth factor $\beta, T G F \beta i$ TGF $\beta$ inhibitor, TNNT troponin T, SALPC sinoatrial node-like progenitor cells, SCF stem cell factor, VEGF vascular endothelial growth factor 
proteins, such as bone morphogenetic proteins (which belong to the transforming growth factor- $\beta$ superfamily), to induce differentiation into the mesoderm. In contrast, 2-dimensional culture involves differentiation methods that use low-molecular-weight compounds such as CHIR99021 (an inhibitor of glycogen synthase kinase $3 \beta$ ) and inhibitors of Wnt, such as IWR-1 and IWP-2. This technology is a cost-effective option for differentiation into cardiomyocytes. Furthermore, twodimensional culture using multilayer culture plates with active gas ventilation has enabled the generation of large quantities of cardiomyocytes that are required for transplantation [17]. No method can achieve 100\% efficiency in cardiomyocyte differentiation, and variations are observed among hiPSC lines and passage numbers; therefore, optimization of the cell differentiation protocol is necessary using specific quantities of pre-optimized reagents to support differentiation into the desired cell types. Development of an efficient method to trigger cardiac differentiation is essential for the large-scale mechanized production of these cells for the realization of transplantation therapy using hiPSC-derived cardiomyocytes. Further research is warranted to develop simpler and more efficient and stable methods.

\section{Cardiomyocyte purification system}

The currently available cardiomyocyte differentiation methods are highly efficient in producing cardiomyocytes. However, if all cells do not differentiate into cardiomyocytes (if the rate of differentiation is not 100\%), there exists an increased risk of tumorigenesis secondary to contamination with non-cardiomyocytes and undifferentiated cells at the time of transplantation. Unfortunately, this factor is a significant barrier to the realization of cardiac regenerative medicine. Therefore, safe transplantation without risk of tumorigenesis necessitates the removal of undifferentiated stem cells and non-cardiomyocytes. Various methods have been reported for the removal of undifferentiated stem cells [21-23] to prevent teratoma formation. Among these studies, we identified glypican-3 (GPC3), a known carcinoembryonic antigen, as a pluripotent state-specific immunogenic antigen. Moreover, we also confirmed that GPC3-reactive cytotoxic T lymphocytes (CTLs) selectively removed undifferentiated PSCs from hiPSC-derivatives in vitro and inhibited tumor formation in vivo [24]. However, contaminating noncardiomyocytes undergoing differentiation may cause tumorigenesis of non-cardiomyocytes. Therefore, we evaluated the applicability of a method for purification of cardiomyocytes alone as a safer transplantation method. Thus, we created a metabolic environment that was conducive to the survival of cardiomyocytes but not undifferentiated stem cells and non-cardiomyocytes. We developed a cardiomyocyte purification medium containing glucose-free lactic acid, which enabled purification of only cardiomyocytes based on the difference in metabolism [25]. Following intensive research focusing on amino acid metabolism, it is known that glutamine is essential for the survival of hiPSCs and that the use of glucose and glutamine-free lactic acid-supplemented medium improves the efficiency of the cardiomyocyte purification method. This knowledge was useful in removing undifferentiated stem cells more efficiently for the purification of cardiomyocytes in a clinical setting [26]. Thus, only cardiomyocytes can be selected in large quantities in a costeffective manner without using genetic modification technology or fluorescence-activated cell sorting. Moreover, tumor formation (teratomas) was not observed even after transplantation of these cells into immunodeficient mice. Therefore, it is reasonable to conclude that this metabolic selection method for differentiated cardiomyocytes can ensure safe regenerative cardiomyocyte transplantation.

\section{Strategy for the transplantation of induced pluripotent stem cell-derived cardiomyocytes}

A previous study investigating regenerative therapy with cardiomyocyte transplantation has reported that iPSCderived cardiomyocytes prepared from skin fibroblasts in patients with heart failure were transplanted into rat hearts and were successfully engrafted [27]. Another study showed that human-ESC (hESC)-derived myocardium transplanted in a guinea pig myocardial infarction model led to improved cardiac function and decrease of ventricular arrhythmias after transplantation [28]. These results indicate the potential utility and feasibility of ESC or iPSC-derived cardiomyocyte transplantation therapy for myocardial regeneration (Table 2). To date, heart cell transplantation is performed by direct injection of the cell suspension into the heart via a syringe, although there is room for improvement in the cell survival rate. Most transplanted cells were observed to be necrotic or an efflux [40]. This observation can be attributed to the fact that the transplanted cardiomyocytes flow out of the myocardium secondary to the beating of the heart, resulting in a low-survival rate. Notably, cell sheet technology is a method of transplantation that involves stacking of multilayered cardiomyocyte sheets to form a scaffold that is transplanted onto the epicardium [41]. However, with this method, the transplanted myocardium may not be electrophysiologically synchronized with the recipient's heart because the epicardium is an electrically insulating tissue. We produced cardiac spheroids with purified cardiomyocytes (approximately $200 \mu \mathrm{m}$ in diameter) and observed that transplantation of these significantly improved the engraftment rate [29, 42]. Cardiomyocyte aggregates do not flow out owing to increased cell adhesion and secretion of cell growth factor and 
Table 2 Transplantation protocols

\begin{tabular}{|c|c|c|c|c|c|c|}
\hline Publication & $\begin{array}{l}\text { Transplantation } \\
\text { Method }\end{array}$ & $\begin{array}{l}\text { Recipient } \\
\text { Animal } \\
\text { Species }\end{array}$ & Recipient Model & $\begin{array}{l}\text { Donor Cell } \\
\text { Type }\end{array}$ & $\begin{array}{l}\text { Number of Donor } \\
\text { Cells }\end{array}$ & Transplantation Efficacy \\
\hline $\begin{array}{l}\text { Hattori F et } \\
\text { al. [29] }\end{array}$ & Direct cell injection & Mouse & Healthy heart & $\begin{array}{l}\text { mESC-CMs } \\
\text { hESC-CMs }\end{array}$ & NA & NA \\
\hline $\begin{array}{l}\text { Zwi-Dantsis L } \\
\text { et al. [27] }\end{array}$ & Direct cell injection & Rat & Healthy heart & hiPSC-CMs & $1.5 \times 10^{5}$ & $\begin{array}{l}\text { Develop gap junctions between donor } \\
\text { hiPSC-CMs and host rat CMs }\end{array}$ \\
\hline $\begin{array}{l}\text { Shiba et al. } \\
{[28]}\end{array}$ & Direct cell injection & Pig & $\begin{array}{l}\text { Cryoinjury induced } \\
\text { infarcted heart }\end{array}$ & hESC-CMs & $1 \times 10^{8}$ & $\begin{array}{l}\text { Reduce ventricular tachycardia } \\
\text { Improve left ventricle fractional shortening }\end{array}$ \\
\hline Ye et al. [30] & Direct cell injection & Pig & $\begin{array}{l}\text { LAD ligation induced } \\
\text { infarcted heart }\end{array}$ & $\begin{array}{l}\text { hiPSC-CMs } \\
\text { hiPSC-EC } \\
\text { hiPSC-SMC } \\
\text { fibrin patch }\end{array}$ & $\begin{array}{l}2 \times 10^{6} \\
2 \times 10^{6} \\
2 \times 10^{6}\end{array}$ & $\begin{array}{l}\text { Improve left ventricle ejection fraction } \\
\text { and infarct size }\end{array}$ \\
\hline $\begin{array}{l}\text { Chong JJ et } \\
\text { al. [31] }\end{array}$ & Direct cell injection & Monkey & $\begin{array}{l}\text { LAD balloon } \\
\text { occlusion induced } \\
\text { infarcted heart }\end{array}$ & hESC-CMs & NA & $\begin{array}{l}\text { Electromechanical coupling between } \\
\text { graft and host myocytes }\end{array}$ \\
\hline $\begin{array}{l}\text { Shiba et al. } \\
\text { [32] }\end{array}$ & Direct cell injection & Monkey & $\begin{array}{l}\text { LAD ligation induced } \\
\text { infarcted heart }\end{array}$ & hiPSC-CMs & $4 \times 10^{8}$ & $\begin{array}{l}\text { Increase ventricular tachycardia transiently } \\
\text { Improve left ventricle ejection fraction and } \\
\text { fractional shortening }\end{array}$ \\
\hline $\begin{array}{l}\text { Liu YW et al. } \\
\text { [33] }\end{array}$ & Direct cell injection & Monkey & $\begin{array}{l}\text { LAD balloon } \\
\text { occlusion induced } \\
\text { infarcted heart }\end{array}$ & hESC-CMs & $7.5 \times 10^{8}$ & $\begin{array}{l}\text { Increase ventricular tachycardia transiently } \\
\text { Improve left ventricle ejection fraction }\end{array}$ \\
\hline $\begin{array}{l}\text { Tabei et al. } \\
\text { [42] }\end{array}$ & Direct cell injection & Pig & Healthy heart & $\begin{array}{l}\text { hiPSC-CM } \\
\text { spheroids }\end{array}$ & $1 \times 10^{7}$ & $\begin{array}{l}\text { The combination of the newly developed } \\
\text { transplant device and spheroid formation } \\
\text { promotes the retention of transplanted CMs }\end{array}$ \\
\hline $\begin{array}{l}\text { Kimura et al. } \\
\text { [34] }\end{array}$ & $\begin{array}{l}\text { Pericardial } \\
\text { endoscopy and } \\
\text { direct injection }\end{array}$ & Pig & Healthy heart & NA & NA & NA \\
\hline $\begin{array}{l}\text { Masumoto } \\
\text { et al. [35] }\end{array}$ & Cell sheets & Rat & $\begin{array}{l}\text { LAD ligation induced } \\
\text { infarcted heart }\end{array}$ & $\begin{array}{l}\text { mESC-CMs } \\
\text { mESC- } \\
\text { ECs\&MCs }\end{array}$ & $\begin{array}{l}5 \times 10^{5} \\
5 \times 10^{5}\end{array}$ & $\begin{array}{l}\text { Improve left ventricle systolic function and } \\
\text { infarct size }\end{array}$ \\
\hline $\begin{array}{l}\text { Suzuki et al. } \\
\text { [36] }\end{array}$ & $\begin{array}{l}\text { Cell sheets } \\
\text { Omentopexy }\end{array}$ & Rat & $\begin{array}{l}\text { LAD ligation induced } \\
\text { infarcted heart }\end{array}$ & $\begin{array}{l}\text { Neonatal } \\
\text { CMs }\end{array}$ & $5.6 \times 10^{5} / \mathrm{cm}^{2}$ & Improve left ventricle ejection fraction \\
\hline $\begin{array}{l}\text { Kashiyama et } \\
\text { al. [37] }\end{array}$ & Cell sheets & Monkey & $\begin{array}{l}\text { LAD ligation induced } \\
\text { infarcted heart }\end{array}$ & $\begin{array}{l}\text { mkiPSC- } \\
\text { CMs }\end{array}$ & $3.6 \times 10^{6} /$ sheet & Improve left ventricle systolic function \\
\hline $\begin{array}{l}\text { Ott HC et al. } \\
\text { [38] }\end{array}$ & $\begin{array}{l}\text { Cell scaffolding } \\
\text { Recellularization }\end{array}$ & Rat & Decellularized heart & $\begin{array}{l}\text { Neonatal } \\
\text { CMs } \\
\text { Fibrocytes } \\
\text { ECs } \\
\text { SMCs }\end{array}$ & $5-7.5 \times 10^{7}$ & Generate working recellularized heart \\
\hline Lu et al. [39] & $\begin{array}{l}\text { Cell scaffolding } \\
\text { Recellularization }\end{array}$ & Mouse & Decellularized heart & hiPSC-MCPs & $1 \times 10^{7}$ & $\begin{array}{l}\text { Generate working recellularized heart } \\
\text { having responsiveness to drugs }\end{array}$ \\
\hline
\end{tabular}

Abbreviations: hiPSC human induced pluripotent stem cell, $m E S C$ mouse embryonic stem cell, $h E S C$ human embryonic stem cell, $m k i P S C$ monkey induced pluripotent stem cell, CMs cardiomyocytes, ECs endothelial cells, SMCs smooth muscle cells, MCs vascular mural cells, MCPs multipotential cardiovascular progenitors, $L A D$ left anterior descending artery, N/A not applicable or not available

increased cell mass size. Additionally, a recent study investigating the effectiveness of hiPSC-derived cardiomyocyte transplantation into a large animal myocardial infarction model such as a pig and monkey model has been reported as a preclinical study to evaluate the safety and efficacy of the clinical application of this approach [30-33], and it is expected that human studies would soon be reported.

\section{Adverse effects of cell transplantation}

Arrhythmias and immune response-mediated transplant rejection are serious adverse events associated with cardiomyocyte transplantation (Fig. 2). A previous study

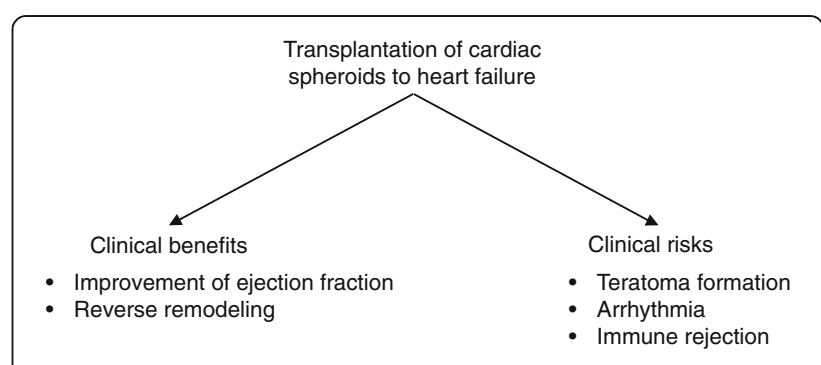

Fig. 2 Clinical benefits and risks of cardiac regenerative therapy 
has reported the development of arrhythmias in patients with severe heart failure who received an injection of skeletal myoblasts [43]. Connexin 43 and N-cadherin, which are essential to establish electrophysiological connections between cardiomyocytes, are not expressed in myoblasts, and automatism associated with myoblasts can precipitate arrhythmias [44]. Previous studies have shown that cardiomyocytes can establish connections with the host heart, and hESC-derived cardiomyocytes can establish electrical connections with neonatal rat cardiomyocytes and become synchronized to beat in vitro [45]. Additionally, it has been shown that transplanted cardiomyocytes demonstrated electrical coupling with the host heart after hESC-derived cardiomyocytes were engrafted to guinea pig hearts [28]. However, several studies have also reported the development of ventricular arrhythmia within the first 2 weeks to 1 month after transplantation into a recipient's heart, which however disappeared a month after cell transplantation $[31,46]$. These data suggest that the arrhythmogenicity of hPSC-derived cardiomyocytes in vivo remains controversial and that it is necessary to closely monitor the heart for arrhythmias after cell transplantation in humans.

Autologous transplantation of iPSCs can realize the goal of cell transplantation without the institution of immunosuppressive therapy. In cases of allogeneic transplantation of iPSCs, controlling the immune response in a recipient is essential for successful engraftment of transplanted cardiomyocytes. Maintaining an iPSC bank is a useful clinical strategy to obtain human leukocyte antigen (HLA)-matched iPSCs, which will obviate the need for immunosuppressant administration in the recipient [47]. However, it should be noted that non-HLAmatched allogeneic cell transplantation requires the administration of a complete immunosuppressive regimen. The immunosuppressive regimen is essentially the same as that prescribed in patients undergoing HT, because the optimal immunosuppressive regimen for cardiac cell transplantation remains unknown. Notably, immunosuppressive therapies can cause adverse effects, such as severe infection and malignancy.

\section{Conclusions}

The realization of cardiac regenerative medicine using hiPSCs requires the efficient and cost-effective largescale production of cardiomyocytes. Avoiding contamination with residual undifferentiated stem cells and noncardiomyocytes is essential and this is the biggest safety challenge in this field. Fortunately, technological advances have facilitated effective strategies for the resolution of these issues. Several preclinical studies performed in large animals (guinea pig and monkey) are ongoing, and much progress has been reported in this realm. It is expected that following complete verification of safety and efficacy, cardiac regenerative medicine using hiPSCs will show wide clinical applicability in humans.

\section{Abbreviations \\ BMP: Bone morphogenetic proteins; ESC: Embryonic stem cell; GPC3: Glypican-3; IPSC: Induced pluripotent stem cell; PSC: Pluripotent stem cell}

\section{Acknowledgements}

Not applicable.

\section{Authors' contributions}

YK, ST, MO, STanosaki, SS, and FJ participated in drafting of the manuscript. $\mathrm{KF}$ reviewed the manuscript. All coauthors have read and approved the final manuscript.

\section{Funding}

This work was supported by the Highway Program for Realization of Regenerative Medicine from the Ministry of Education, Culture, Sports, Science and Technology of Japan (to KF, no. 19bk0104062h0003), a Grant-in-Aid for Scientific Research from the Ministry of Education, Culture, Sports, Science and Technology (to JF, no. 19H03660, to ST., no. 17H05067), Projects for Technological Development, Research Center Network for Realization of Regenerative Medicine by Japan, the Japan Agency for Medical Research and Development (to ST, no. 19bm0404023h0002), and JSPS KAKENHI (to ST, no. 17H05067).

\section{Availability of data and materials}

Not applicable.

Ethics approval and consent to participate

Not applicable.

\section{Consent for publication}

Not applicable.

\section{Competing interests}

JF, ST, and KF own equity in Heartseed, Inc. KF is the CEO of Heartseed, Inc. and receives a salary from Heartseed, Inc. YK, MO, STanosaki, and SS have no conflicts of interest to declare.

Received: 19 July 2019 Accepted: 19 December 2019

Published online: 13 January 2020

\section{References}

1. Takahashi K, Yamanaka S. Induction of pluripotent stem cells from mouse embryonic and adult fibroblast cultures by defined factors. Cell. 2006;126(4): $663-76$

2. Takahashi K, Tanabe K, Ohnuki M, Narita M, Ichisaka T, Tomoda K, et al. Induction of pluripotent stem cells from adult human fibroblasts by defined factors. Cell. 2007;131(5):861-72.

3. Yuasa S, Fukuda K. Recent advances in cardiovascular regenerative medicine: the induced pluripotent stem cell era. Expert Rev Cardiovasc Ther. 2008:6(6):803-10.

4. Kehat I, Kenyagin-Karsenti D, Snir M, Segev H, Amit M, Gepstein A, et al. Human embryonic stem cells can differentiate into myocytes with structural and functional properties of cardiomyocytes. J Clin Invest. 2001;108(3): 407-14.

5. Laflamme MA, Chen KY, Naumova AV, Muskheli V, Fugate JA, Dupras SK, et al. Cardiomyocytes derived from human embryonic stem cells in prosurvival factors enhance function of infarcted rat hearts. Nature Biotechnol. 2007;25(9):1015-24.

6. Yang L, Soonpaa MH, Adler ED, Roepke TK, Kattman SJ, Kennedy M, et al. Human cardiovascular progenitor cells develop from a KDR+ embryonicstem-cell-derived population. Nature. 2008:453(7194):524-8.

7. Tran TH, Wang X, Browne $C$, Zhang $Y$, Schinke M, Izumo S, et al. Wnt3ainduced mesoderm formation and cardiomyogenesis in human embryonic stem cells. Stem Cells. 2009;27(8):1869-78. 
8. Elliott DA, Braam SR, Koutsis K, Ng ES, Jenny R, Lagerqvist EL, et al. NKX2 $5($ GGFP/w) hESCs for isolation of human cardiac progenitors and cardiomyocytes. Nature Methods. 2011;8(12):1037-40.

9. Kattman SJ, Witty AD, Gagliardi M, Dubois NC, Niapour M, Hotta A, et al. Stage-specific optimization of activin/nodal and BMP signaling promotes cardiac differentiation of mouse and human pluripotent stem cell lines. Cell Stem Cell. 2011;8(2):228-40.

10. Zhang Q, Jiang J, Han P, Yuan Q, Zhang J, Zhang X, et al. Direct differentiation of atrial and ventricular myocytes from human embryonic stem cells by alternating retinoid signals. Cell Res. 2011;21(4):579-87.

11. Willems E, Spiering S, Davidovics H, Lanier M, Xia Z, Dawson M, et al. Smallmolecule inhibitors of the Wnt pathway potently promote cardiomyocytes from human embryonic stem cell-derived mesoderm. Circ Res. 2011;109(4): 360-4.

12. Zhang J, Klos M, Wilson GF, Herman AM, Lian X, Raval KK, et al. Extracellular matrix promotes highly efficient cardiac differentiation of human pluripotent stem cells: the matrix sandwich method. Circ Res. 2012;111(9): $1125-36$.

13. Lian X, Zhang J, Azarin SM, Zhu K, Hazeltine LB, Bao X, et al. Directed cardiomyocyte differentiation from human pluripotent stem cells by modulating Wnt/beta-catenin signaling under fully defined conditions. Nat Protoc. 2013;8(1):162-75.

14. Burridge PW, Matsa E, Shukla P, Lin ZC, Churko JM, Ebert AD, et al. Chemically defined generation of human cardiomyocytes. Nat Methods. 2014;11(8):855-60.

15. Devalla HD, Schwach V, Ford JW, Milnes JT, El-Haou S, Jackson C, et al. Atrial-like cardiomyocytes from human pluripotent stem cells are a robust preclinical model for assessing atrial-selective pharmacology. EMBO Mol Med. 2015;7(4):394-410.

16. Protze SI, Liu J, Nussinovitch U, Ohana L, Backx PH, Gepstein L, et al. Sinoatrial node cardiomyocytes derived from human pluripotent cells function as a biological pacemaker. Nat Biotechnol. 2017;35(1):56-68.

17. Tohyama S, Fujita J, Fujita C, Yamaguchi M, Kanaami S, Ohno R, et al. Efficient Large-Scale 2D Culture System for Human Induced Pluripotent Stem Cells and Differentiated Cardiomyocytes. Stem Cell Rep. 2017;9(5):1406-14.

18. Fujita J, Tohyama S, Kishino Y, Okada M, Morita Y. Concise Review: Genetic and epigenetic regulation of cardiac differentiation from human pluripotent stem cells. Stem Cells. 2019.

19. Zhang J, Wilson GF, Soerens AG, Koonce CH, Yu J, Palecek SP, et al. Functional cardiomyocytes derived from human induced pluripotent stem cells. Circulation research. 2009;104(4):e30-41.

20. Hemmi N, Tohyama S, Nakajima K, Kanazawa H, Suzuki T, Hattori F, et al. A massive suspension culture system with metabolic purification for human pluripotent stem cell-derived cardiomyocytes. Stem Cells Transl Med. 2014; 3(12):1473-83.

21. Kuang Y, Miki K, Parr CJC, Hayashi K, Takei I, Li J, et al. Efficient, Selective Removal of Human Pluripotent Stem Cells via Ecto-Alkaline PhosphataseMediated Aggregation of Synthetic Peptides. Cell Chem Biol. 2017;24(6): 685-94 e4.

22. Tateno $H$, Onuma $Y$, Ito $Y$, Minoshima F, Saito S, Shimizu M, et al. Elimination of tumorigenic human pluripotent stem cells by a recombinant lectin-toxin fusion protein. Stem Cell Rep. 2015;4(5):811-20.

23. Parr CJ, Katayama S, Miki K, Kuang Y, Yoshida Y, Morizane A, et al. MicroRNA-302 switch to identify and eliminate undifferentiated human pluripotent stem cells. Sci Rep. 2016;6:32532

24. Okada M, Tada Y, Seki T, Tohyama S, Fujita J, Suzuki T, et al. Selective elimination of undifferentiated human pluripotent stem cells using pluripotent state-specific immunogenic antigen Glypican-3. Biochem Biophys Res Commun. 2019;511(3):711-7.

25. Tohyama S, Hattori F, Sano M, Hishiki T, Nagahata Y, Matsuura T, et al. Distinct metabolic flow enables large-scale purification of mouse and human pluripotent stem cell-derived cardiomyocytes. Cell Stem Cell. 2013;12(1):127-37.

26. Tohyama S, Fujita J, Hishiki T, Matsuura T, Hattori F, Ohno R, et al. Glutamine Oxidation Is Indispensable for Survival of Human Pluripotent Stem Cells. Cell Metabol. 2016;23(4):663-74

27. Zwi-Dantsis L, Huber I, Habib M, Winterstern A, Gepstein A, Arbel G, et al. Derivation and cardiomyocyte differentiation of induced pluripotent stem cells from heart failure patients. Eur Heart J. 2013;34(21):1575-86.

28. Shiba Y, Fernandes S, Zhu WZ, Filice D, Muskheli V, Kim J, et al. Human EScell-derived cardiomyocytes electrically couple and suppress arrhythmias in injured hearts. Nature. 2012;489(7415):322-5.
29. Hattori F, Chen H, Yamashita H, Tohyama S, Satoh YS, Yuasa S, et al. Nongenetic method for purifying stem cell-derived cardiomyocytes. Nature Methods. 2010;7(1):61-6.

30. Ye L, Chang YH, Xiong Q, Zhang P, Zhang L, Somasundaram P, et al. Cardiac repair in a porcine model of acute myocardial infarction with human induced pluripotent stem cell-derived cardiovascular cells. Cell stem cell. 2014;15(6):750-61.

31. Chong JJ, Yang X, Don CW, Minami E, Liu YW, Weyers JJ, et al. Human embryonic-stem-cell-derived cardiomyocytes regenerate non-human primate hearts. Nature. 2014;510(7504):273-7.

32. Shiba Y, Gomibuchi T, Seto T, Wada Y, Ichimura H, Tanaka Y, et al. Allogeneic transplantation of iPS cell-derived cardiomyocytes regenerates primate hearts. Nature. 2016;538(7625):388-91.

33. Liu YW, Chen B, Yang X, Fugate JA, Kalucki FA, Futakuchi-Tsuchida A, et al. Human embryonic stem cell-derived cardiomyocytes restore function in infarcted hearts of non-human primates. Nature biotechnology. 2018;36(7): 597-605.

34. Kimura T, Miyoshi S, Okamoto K, Fukumoto K, Tanimoto K, Soejima K, et al. The effectiveness of rigid pericardial endoscopy for minimally invasive minor surgeries: cell transplantation, epicardial pacemaker lead implantation, and epicardial ablation. J Cardiothorac Surg. 2012;7:117.

35. Masumoto H, Matsuo T, Yamamizu K, Uosaki H, Narazaki G, Katayama S, et al. Pluripotent stem cell-engineered cell sheets reassembled with defined cardiovascular populations ameliorate reduction in infarct heart function through cardiomyocyte-mediated neovascularization. Stem Cells. 2012;30(6):1196-205.

36. Suzuki R, Hattori F, Itabashi Y, Yoshioka M, Yuasa S, Manabe-Kawaguchi H, et al. Omentopexy enhances graft function in myocardial cell sheet transplantation. Biochem Biophys Res Commun. 2009;387(2):353-9.

37. Kashiyama N, Miyagawa S, Fukushima S, Kawamura T, Kawamura A, Yoshida $\mathrm{S}$, et al. MHC-mismatched Allotransplantation of Induced Pluripotent Stem Cell-derived Cardiomyocyte Sheets to Improve Cardiac Function in a Primate Ischemic Cardiomyopathy Model. Transplantation. 2019;103(8):1582-90.

38. Ott HC, Matthiesen TS, Goh SK, Black LD, Kren SM, Netoff TI, et al. Perfusiondecellularized matrix: using nature's platform to engineer a bioartificial heart. Nat Med. 2008;14(2):213-21.

39. Lu TY, Lin B, Kim J, Sullivan M, Tobita K, Salama G, et al. Repopulation of decellularized mouse heart with human induced pluripotent stem cellderived cardiovascular progenitor cells. Nat Commun. 2013;4:2307.

40. Hattan N, Kawaguchi H, Ando K, Kuwabara E, Fujita J, Murata M, et al. Purified cardiomyocytes from bone marrow mesenchymal stem cells produce stable intracardiac grafts in mice. Cardiovasc Res. 2005;65(2):334-44.

41. Fujita J, Itabashi Y, Seki T, Tohyama S, Tamura Y, Sano M, et al. Myocardial cell sheet therapy and cardiac function. Am J Physiol Heart Circ Physiol. 2012:303(10):H1169-82.

42. Tabei R, Kawaguchi S, Kanazawa H, Tohyama S, Hirano A, Handa N, et al. Development of a transplant injection device for optimal distribution and retention of human induced pluripotent stem cellderived cardiomyocytes. J Heart Lung Transplant. 2019;38(2):203-14.

43. Menasche P, Alfieri O, Janssens S, McKenna W, Reichenspurner H, Trinquart L, et al. The Myoblast Autologous Grafting in Ischemic Cardiomyopathy (MAGIC) trial: first randomized placebo-controlled study of myoblast transplantation. Circulation. 2008;117(9):1189-200.

44. Itabashi Y, Miyoshi S, Yuasa S, Fujita J, Shimizu T, Okano T, et al. Analysis of the electrophysiological properties and arrhythmias in directly contacted skeletal and cardiac muscle cell sheets. Cardiovasc Res. 2005;67(3):561-70.

45. Thompson SA, Burridge PW, Lipke EA, Shamblott M, Zambidis ET, Tung L. Engraftment of human embryonic stem cell derived cardiomyocytes improves conduction in an arrhythmogenic in vitro model. J Mol Cell Cardiol. 2012:53(1):15-23.

46. Romagnuolo R, Masoudpour H, Porta-Sanchez A, Qiang B, Barry J, Laskary A, et al. Human Embryonic Stem Cell-Derived Cardiomyocytes Regenerate the Infarcted Pig Heart but Induce Ventricular Tachyarrhythmias. Stem Cell Rep. 2019;12(5):967-81.

47. Morizane A, Doi D, Kikuchi T, Okita K, Hotta A, Kawasaki T, et al. Direct comparison of autologous and allogeneic transplantation of iPSC-derived neural cells in the brain of a non-human primate. Stem Cell Rep. 2013;1(4): 283-92.

\section{Publisher's Note}

Springer Nature remains neutral with regard to jurisdictional claims in published maps and institutional affiliations. 